\title{
Association between the number of steps performed during work and metabolic syndrome indicators in São Paulo city military police officers: The health promotion of Military Police (HPMP) study
}

Associação entre o número de passos realizados durante o trabalho e indicadores da síndrome metabólica em policiais militares da cidade de São Paulo: Estudo de promoção da saúde da Polícia Militar (HPMP)

Asociación entre el número de pasos realizados durante el trabajo y los indicadores de síndrome metabólico en policías militares de la ciudad de São Paulo: Estudio de promoción de la salud de la Policía Militar (HPMP)

Leandro Porto dos Santos ORCID: https://orcid.org/0000-0002-9054-6108 Cruzeiro do Sul University, Brazil E-mail: leandro.prof.edfi@gmail.com

Diego Ribeiro de Souza ORCID: https://orcid.org/0000-0003-2088-9356 Military Police of São Paulo State, Brazil E-mail: diegors@policiamilitr.sp.gov.br

Renata Gorjao

ORCID: https://orcid.org/0000-0002-9655-1477 Cruzeiro do Sul University, Brazil

E-mail: renata.gorjao@cruzeirodosul.edu.br

Adriana Cristina Levada-Pires ORCID: https://orcid.org/0000-0002-5320-5953 Cruzeiro do Sul University, Brazil

E-mail: adriana.pires@cruzeirodosul.edu.br

Elaine Hatanaka

ORCID: https://orcid.org/0000-0002-9716-1163 Cruzeiro do Sul University, Brazil

E-mail: elaine.hatanaka@cruzeirodosul.edu.br

Maria Fernanda Cury-Boaventura ORCID: https://orcid.org/0000-0002-7523-4616 Cruzeiro do Sul University, Brazil E-mail: maria.boaventura@cruzeirodosul.edu.br

Douglas Vicente Russo Junior ORCID: https://orcid.org/0000-0001-9594-2006 Cruzeiro do Sul University, Brazil E-mail: douglas.russojr@gmail.com Odair Bacca

ORCID: https://orcid.org/0000-0002-5275-5777 Cruzeiro do Sul University, Brazil E-mail: odairbacca@gmail.com Eliane Borges da Silva

ORCID: https://orcid.org/0000-0002-9181-8822 Cruzeiro do Sul University, Brazil

E-mail: eliane_borges91@ @otmail.com

Raquel Freitas Zambonatto

ORCID: https://orcid.org/0000-0003-2144-1449 Cruzeiro do Sul University, Brazil

E-mail: zambonattoraquel@gmail.com Laureane Nunes Masi ORCID: https://orcid.org/0000-0001-9472-7304 Cruzeiro do Sul University, Brazil E-mail: laure_masi@hotmail.com 
Roberto Barbosa Bazotte

ORCID: https://orcid.org/0000-0002-9018-4944

State University of Maringá, Brazil E-mail: rbbazotte@gmail.com

Rui Curi

ORCID: https://orcid.org/0000-0001-5095-9154

Cruzeiro do Sul University, Brazil

E-mail: ruicuri59@gmail.com

Tania Cristina Pithon-Curi

ORCID: https://orcid.org/0000-0002-9714-9105

Cruzeiro do Sul University, Brazil

E-mail: tania.pithon-curi@ cruzeirodosul.edu.br

Sandro Massao Hirabara

ORCID: https://orcid.org/0000-0002-7392-0444

Cruzeiro do Sul University, Brazil

E-mail: sandro.hirabara@cruzeirodosul.edu.br

\begin{abstract}
We evaluated the working number steps (STEPS) of 25 military police officers (MPOs: day shift $\mathrm{n}=14$ and night shift $\mathrm{n}=11$ ) from the Military Police of São Paulo State (PMESP) while patrolling São Paulo city center and its association with metabolic syndrome (MetS) indicators. The participants' body composition and anthropometric parameters: body mass index (BMI), fat-free mass (FFM), skeletal muscle mass (SMM) and clinical and laboratory data: systolic (SBP) and diastolic (DBP) blood pressure, and fasting plasma levels of glucose, glycated hemoglobin A1c (HbA1c), insulin, HDL-cholesterol, triacylglycerol (TG), and C-reactive protein (CRP) were also measured. According to the number of steps taken during the daily $12 \mathrm{~h}$ working period, the MPOs were divided into three groups: $600-2,000,2,001-8,000$, and $>8,000$ steps. On average, each participant took $5169 \pm 614$ steps per $12 \mathrm{~h}$ shift. While MPOs from the night shift walked $25 \%$ more than the day shift (6188 \pm 1069 vs. $4367 \pm 664)$, this difference was not statistically significant. Notably, the BMI, FFM (13.4\%), SMM (14.5\%), plasma HDL-cholesterol levels (32.2\%), and DBP (19.1\%) were significantly higher in group 1 compared to the other two groups. Furthermore, reduced physical activity, age, BMI, and tenure at PMESP were associated with increased MetS indicators. Overall, MPOs performing less than 2,000 steps per shift presented marked changes in body composition and plasma measurements and a higher MetS prevalence (64\%) than those who were more physically active.
\end{abstract}

Keywords: Body composition; Occupational medicine; Metabolic diseases; Cardiovascular diseases; Physical activity level.

\title{
Resumo
}

Avaliamos o número de passos (STEPS) de 25 policiais militares (PMs: diurno $n=14$ e noturno $n=11$ ) da Polícia Militar do Estado de São Paulo (PMESP) durante o patrulhamento no centro de São Paulo e sua associação com os indicadores de síndrome metabólica (SM). A composição corporal e os parâmetros antropométricos dos participantes: índice de massa corporal (IMC), massa livre de gordura (MLG), massa muscular esquelética (MME) e dados clínicos e laboratoriais: pressão arterial sistólica (PAS) e diastólica (PAD), concentrações plasmáticas de glicose em jejum, hemoglobina glicada A1c (HbA1c), insulina, HDL-colesterol, triacilglicerol (TG) e proteína C reativa (PCR). De acordo com o número de passos realizados durante as 12 horas diárias de trabalho, os PMs foram divididos em três grupos: 600-2.000, 2.001-8.000 e > 8.000 passos. Em média, os participantes deram $5.169 \pm 614$ passos por turno de 12 horas. Os PMs do período noturno caminharam $25 \%$ mais do que no turno do dia (6188 \pm 1069 vs. $4367 \pm 664)$, essa diferença não foi estatisticamente significativa. Notavelmente, o IMC, MLG (13,4\%), MME (14,5\%), níveis plasmáticos de HDL-colesterol $(32,2 \%)$ e PAD $(19,1 \%)$ foram significativamente maiores no grupo 1 em comparação com os outros dois grupos. Além disso, a redução da atividade física, idade, IMC e tempo de permanência na PMESP foram associados com o aumento dos indicadores de SM. No geral, os PMs que executam menos de 2.000 passos por turno apresentaram alterações na composição corporal, plasmáticas e uma prevalência mais elevada de SM (64\%) do que aqueles que se apresentaram fisicamente mais ativos.

Palavras-chave: Composição corporal; Medicina do trabalho; Doenças metabólicas; Doenças cardiovasculares; Nível de atividade física.

\section{Resumen}

Se evaluó el número de pasos (STEPS) en 25 policías militares (MPOs: diurno $\mathrm{n}=14$ y nocturno $\mathrm{n}=11$ ) del Estado de São Paulo (PMESP) durante el patrullaje en el centro de São Paulo y su asociación con indicadores de síndrome metabólico (MetS). Adicionalmente, fue medida la composición corporal y los parámetros antropométricos de los participantes: Índice de Masa CorporaSel (IMC), masa libre de grasa (FFM), masa de músculo esquelético (SMM); así como los datos clínicos y de laboratorio: presión arterial sistólica (PAS) y diastólica (PAD), niveles plasmáticos en glucosa en ayunas, hemoglobina glicosilada A1c (HbA1c), insulina, colesterol HDL, triacilglicerol (TG) y proteína C reactiva (PCR). De acuerdo con el número de pasos realizados durante las 12 horas diarias de trabajo, las MPO se dividieron en tres grupos: 600-2.000, 2.001-8.000 y > 8.000 pasos. En promedio, los participantes realizaron $5169 \pm$ 
614 pasos por turno de $12 \mathrm{~h}$. Mientras que los MPO del periodo nocturno caminaron un $25 \%$ más que los del periodo diurno (6188 \pm 1069 vs. $4367 \pm 664)$, esta diferencia no fue estadísticamente significativa. En cuanto al IMC, FFM $(13,4 \%)$, SMM (14,5\%), niveles plasmáticos de colesterol HDL $(32,2 \%)$ y PAD $(19,1 \%)$, el grupo que caminó entre 600-2000 pasos mostró valores significativamente más altos en comparación con los demás grupos. Adicionalmente, la edad, disminución de la actividad física, IMC y la permanencia en el PMESP fueron asociadas con un aumento en los indicadores de MetS. En general, las MPO que realizaron menos de 2000 pasos por turno, presentaron alteraciones de composición corporal y plasma, así como una mayor prevalencia de MetS (64\%) comparado con los policías que fueron categorizados como físicamente activos.

Palabras clave: Composición corporal; Medicina del trabajo; Enfermedades metabólicas; Enfermedades cardiovasculares; Nivel de actividad física.

\section{Introduction}

The World Health Organization (WHO, 2020) defines physical activity as any bodily movement produced by skeletal muscle that requires energy (Bull, et al., 2020). It has been demonstrated that regular physical activity is associated with reduced plasma triacylglycerol (TG) levels, visceral adipose tissue size, and lipid accumulation in the body, preventing obesity and several obesity-related diseases, including metabolic syndrome (MetS), type 2 diabetes mellitus, and cardiovascular disease (CVD) (Friedenreich, et al., 2015; Green, et al., 2014; McPhee, et al., 2016; Vissers, et al., 2013). Additionally, regular physical activity attenuates primary and secondary mortality due to CVD, hypertension, obesity, diabetes, cancer, depression, and osteoporosis (Ekblom-Bak, et al., 2021; Warburton, et al., 2006). Notably, physical activity is considered comparable to pharmacological therapies for treating stroke patients (Hoffmann, et al., 2016; Thornton, et al., 2016).

In 2004, the American College of Sports Medicine (ACSM) established five physical activity classification levels depending on the number of steps taken per day: 1) <5,000 steps/day (sedentary); 2) 5,001-7,499 steps/day (little active); 3) 7,500-9,999 steps/day (slightly active); 4) 10,000-12,499 steps/day (active); and 5) $\geq 12,500$ steps/day (highly active). Five years later, Tudor-Loke et al., (2009) introduced two additional graduations to the "sedentary" level: <2,500 steps/day (basal activity) and 2,501-4,999 steps/day (limited activity) (Tudor-Locke, et al., 2009). It has been recommended that adults (26-65 years) perform at least 7,000 steps per day (Tudor-Locke, et al., 2011). More recently, the ACSM established that each increment from 2,000 daily steps to 10,000 steps is associated with a 10\% reduction in adverse cardiovascular events (Kraus, et al., 2019). In addition, walking 30 min a day, five days a week, reduces the risk of cardiovascular incidents by $19 \%$ (Murtagh, et al., 2010). Indeed, there is an inverse relationship between physical activity and chronic diseases, and a 20-30\% reduction in premature death in physically active individuals (Paterson \& Warburton, 2010; Warburton \& Bredin, 2016)

In recent years, chronic non-communicable diseases associated with morbidity and mortality have markedly increased, and physical inactivity is one of the critical factors (Lavie, et al., 2019; Myers, et al., 2019). Despite the widespread acceptance of physical exercise's beneficial effects (Penedo \& Dahn, 2005), a third of the world's population is considered sedentary (JI, 2019). Merino (2010) investigated cardiovascular and metabolic changes and the leading causes of death in the Military Police of São Paulo State (PMESP) compared to the São Paulo city civilian population between 2002 and 2006. This author reported that military police officers (MPOs) aged between 20 and 54 had mortality rates that were 2.5 and 4 times higher due to CVD and liver disease, respectively, compared to the civil population in the same age range. Additionally, Merino found that during the first ten years of service (i.e., 20-29 years of age), MPOs have a lower CVD-related mortality rate than the civilian population with the same age range. On the other hand, in the last ten years of service, deaths due to CVD were 3.5 and 2.9 times higher for MPOs between 45-49 and 50-54 years old, respectively, compared to the civilian São Paulo city population (Merino, 2010).

In a recent study, Souza (2021) reported that São Paulo city MPOs are overweight or obese and that $43 \%$ exhibit MetS. A high MetS incidence was also detected among MPOs from Bahia, Brazil, reaching 38.5\% of the total force (Filho \& D’Oliveira Jr, 2014) and in police officers from other countries, including India (Tharkar, et al., 2008), the USA (Baughman et 
al., 2016; Violanti, et al., 2009), Taiwan (Chang, et al., 2015), Italy (Garbarino \& Magnavita, 2015), and Iran (Payab, et al., 2017). According to the studies cited, increased caloric ingestion, sleep restriction, stress, and a sedentary lifestyle were associated with elevated CVD and metabolic disease risks. In addition to insulin resistance, type-2 diabetes, and CVD (Bazotte et al., 2014; Grundy et al., 2004), MetS patients exhibit a spectrum of disease-related clinical conditions, including obesity, dyslipidemia, and hyperglycemia (Esposito, et al., 2012; Neeland, et al., 2019; Neeland, et al., 2018).

The present study investigated the number of steps performed during a $12 \mathrm{~h}$ day or night shift patrolling São Paulo city center and MetS indicators. We also evaluated the association of age, PMESP service time, and BMI with MetS indicators in the same volunteers.

\section{Methodology}

\section{Recruitment of the participants}

The present study was carried out at the Institute of Sport Sciences and Physical Activity (ICAFE) at Cruzeiro do Sul University (UNICSUL) in São Paulo, SP, Brazil, as previously described by Souza et al. (2021). The MPOs from Metropolitan Police Command Area 1 work in the radio patrol program in the São Paulo city center and participated in a previous study (Souza et al., 2021). Initially, 51 MPOs were recruited to monitor physical activity levels using a pedometer (YamaxDigiWalker SW 700, Tokyo, Japan) during their patrols. The volunteers were separated according to day $(\mathrm{n}=29)$ or night $(\mathrm{n}=22)$ shift. In the São Paulo city radio patrol, officers work $12 \mathrm{~h}$ shifts [i.e., 6:00 am to 6:00 pm (day shift), or 6:00 pm to 6:00 am (night shift)] followed by $36 \mathrm{~h}$ of rest. Twenty-one volunteers did not correctly fill out the daily registration form (DRF) and were excluded. Thus, 25 participants completed the study ( $n=14$ for the day shift and $n=11$ for the night shift). The Ethics Committee at Cruzeiro do Sul University (Protocol number 08905019.4.0000.8084) approved the study.

\section{Experimental procedure}

Questionnaire application, blood collection, and plasma measurements were performed at the ICAFE at UNICSUL. All participants were instructed to fast for at least $8 \mathrm{~h}$ before all assessments.

\section{Body composition and anthropometric measurements (Table 1)}

The height, measured using a stadiometer, and body mass (BM) of each volunteer were used to calculate the body mass index (BMI). Skeletal muscle mass (SMM; Kg), fat-free mass (FFM; Kg), absolute fat mass (AFM; Kg), and visceral adipose tissue (VAT; L) were determined using eight-point bioelectrical impedance analysis, with a SECA 515 medical Body Composition Analyzer (mBCA) (Hamburg, Germany), according to a previous study (Bosy-Westphal, et al., 2013). Hip circumference (HC; cm)and waist circumference (WC; $\mathrm{cm}$ ) was measured following the method of Onis et al., (1996). The waist-to-hip ratio (WHR) was calculated using WC and HC data. The same protocol was used in our previous study (de Souza, et al., 2018).

\section{Characteristics of the participants (Table 1)}

The average age (years) of the 25 volunteers was $33.5 \pm 1.36$. The age (years) of MPOs working the day shift ranged from 27 to 44 (35.5 \pm 1.57 ). The age of MPOs working the night shift ranged from 24 to 47 (30.7 \pm 2.17 ). Participant percentage distribution by age was $21.4 \%$ and $54.5 \%(\leq 30), 50 \%$ and $36.4 \%$ (31 to 40 ), and $28.6 \%$ and $9.1 \%$ ( $\geq 41)$ for the day and night shifts, respectively. PMESP service time ranged from 3 to 23 years $(10.4 \pm 2.15)$ for the MPOs working the day shift and from 2 to 16 years $(6.00 \pm 1.51)$ for those working the night shift; the average for both shifts was $8.20 \pm 1.40$ years. Service time 
percentage distribution was $50 \%$ and $82 \%$ ( $\leq 5$ years), $28.5 \%$ and $18 \%(10-20)$, and $21.5 \%$ and $0 \%(\geq 21)$ for the day and night shift groups, respectively. It should be pointed out that newcomer MPOs predominate the night shift. The individual and average values \pm standard error of the means (SEM) are presented in Table 1.

The BM ranged from 73.2 to $127 \mathrm{Kg}(88.6 \pm 3.75)$ and 60.3 to $111 \mathrm{Kg}(85.7 \pm 4.31)$ for the MPOs working the day and night shifts, respectively. The average BM was $87.1 \pm 2.68 \mathrm{Kg}$ for both groups. Height varied from 1.62 to 1.89 meters (1.76 \pm 0.01$)$. The BMI $(\mathrm{Kg} / \mathrm{m} 2)$ of the 25 volunteers was $28.3 \pm 0.93$. Notably, the BMI varied markedly between the day and night groups. According to the WHO BMI classification (1998), of the 14 MPOs working the day shift, three were eutrophic (21.5\%), eight were overweight (57\%), and three were obese (21.5\%). Of the 11 MPOs working the night shift, two were eutrophic (18.2\%), five were overweight (45.4\%), and four were obese (36.4\%). The AFM of day shift MPOs ranged from 13.7 to $56.1 \mathrm{Kg}(\Delta=42.3)$ and 7.96 to $36.2 \mathrm{~kg}(\Delta=28.2)$ in the night shift group. The FFM of day shift MPOs ranged from 57.5 to $74.1 \mathrm{Kg}(\Delta=16.7)$ and 49.8 to $75.0 \mathrm{~kg}(\Delta=25.1)$ in the night shift group. The SMM of day shift MPOs ranged from 27.6 to $37.5 \mathrm{~kg}(\Delta=9.87)$ and 24.0 to $38.2 \mathrm{~kg}(\Delta=14.2)$ in the night shift group. The average VAT value of the 25 volunteers was $3.3 \pm 0.35 \mathrm{~L}$, ranging from 2.00 to $9.78 \mathrm{~L}(\Delta=7.78)$ in the day shift MPOs and 1.46 to $3.35 \mathrm{~L}(\Delta=1.89)$ in the night shift group.

The HC was $103.5 \pm 1.71 \mathrm{~cm}$, and the WC was $96.8 \pm 2.4 \mathrm{~cm}$ for the 25 volunteers. The HC values ranged from 93.5 to $128 \mathrm{~cm}(\Delta=34.5 \mathrm{~cm} ; 104 \pm 2.44)$ in the MPOs working the day shift and 90 to $116 \mathrm{~cm}(\Delta=26 \mathrm{~cm} ; 103 \pm 2.47)$ for those working the night shift. The WC ranged from 79 to $126 \mathrm{~cm}(\Delta=47 \mathrm{~cm} ; 96.3 \pm 3.52)$ in the MPOs working the day shift and 84 to $116 \mathrm{~cm}$ $(\Delta=32 \mathrm{~cm} ; 97.4 \pm 3.44)$ in the night shift group. Nine MPOs working the day shift $(64.4 \%)$ and eight from the night shift (72.7\%) had a WC greater than $90 \mathrm{~cm}$.

According to the WHO WHR classification (1998), six volunteers working the day shift were at moderate risk for developing CVD, three were at high risk, and six were at very high risk. Of the MPOs working the night shift, one was at low risk of developing CVD, six were at high risk, and four were at very high risk. When considering all 25 participants, $28 \%$ were at moderate risk for developing CVD, $32 \%$ were at high risk, and $40 \%$ were at very high risk.

\section{Physical activity during the working period}

Physical activity (i.e., number of steps) was monitored during the day and night patrol shifts. Briefly, participants were initially instructed to use the pedometer and complete the daily record form (DRF), indicating when the device was placed on and removed from the body. The MPOs used a pedometer for three $12 \mathrm{~h}$ working periods. The first period was dedicated to training the MPOs on using the pedometer. Each device was set up considering each police officers' body mass and step length (Schneider, et al., 2003). At the end of the patrol shift, the volunteers registered the number of steps performed in the DRF. Every day volunteers were reminded by text message via the WhatsApp application about using the device and recording data in the DRF at the beginning and end of the workday. The average number of steps was calculated using the data from two patrol shifts. 
Table 1. Age, years of service at the PMESP, and body composition in military police officers working the day ( $\mathrm{n}=14$ ) and night $(\mathrm{n}=11)$ shifts and total sample $(\mathrm{n}=25)$. [São Paulo City, São Paulo State, Brazil, 2018].

\begin{tabular}{|c|c|c|c|c|c|c|c|c|c|c|c|c|}
\hline \multicolumn{13}{|c|}{ DAY SHIFT (n=14) } \\
\hline & Age & Years* & $\begin{array}{l}\text { BM } \\
(\mathbf{K g})\end{array}$ & $\begin{array}{c}\text { Height } \\
\text { (m) }\end{array}$ & $\underset{\left(\mathbf{K g} / \mathbf{m}^{2}\right)}{\text { BMI }}$ & $\begin{array}{c}\text { AFM } \\
(\mathbf{K g})\end{array}$ & $\begin{array}{c}\text { FFM } \\
(\mathbf{K g})\end{array}$ & $\begin{array}{c}\text { SMM } \\
(\mathbf{K g})\end{array}$ & $\begin{array}{c}\text { VAT } \\
(\mathbf{L})\end{array}$ & $\begin{array}{l}\text { WC } \\
(\mathrm{cm})\end{array}$ & $\begin{array}{c}\mathrm{HC} \\
(\mathrm{cm})\end{array}$ & $\begin{array}{c}\text { WHR } \\
\text { (m) }\end{array}$ \\
\hline 1 & 34 & 11 & 84.3 & 1.79 & 26.3 & 20.7 & 63.6 & 31.5 & 2.73 & 93.5 & 102.0 & 0.92 \\
\hline 2 & 31 & 3 & 91.9 & 1.84 & 27.1 & 17.8 & 74.1 & 37.5 & 2.00 & 87.0 & 103.0 & 0.84 \\
\hline 3 & 43 & 23 & 98.8 & 1.78 & 31.2 & 41.2 & 57.6 & 28.5 & 3.38 & 111.0 & 115.0 & 0.97 \\
\hline 4 & 29 & 4 & 78.5 & 1.77 & 25.1 & 16.0 & 62.5 & 31 & 1.98 & 84.0 & 97.0 & 0.87 \\
\hline 5 & 43 & 23 & 91.0 & 1.79 & 28.4 & 30.2 & 60.7 & 30.5 & 3.27 & 104.0 & 104.0 & 1.00 \\
\hline 6 & 43 & 22 & 127 & 1.79 & 39.6 & 56.1 & 71.3 & 35.8 & 9.78 & 126.0 & 128.0 & 0.98 \\
\hline 7 & 35 & 4 & 86.3 & 1.75 & 28.2 & 27.6 & 58.7 & 28.6 & 3.85 & 97.0 & 101.0 & 0.96 \\
\hline 8 & 30 & 3 & 81.5 & 1.89 & 22.8 & 19.8 & 63.3 & 31.1 & 3.39 & 79.0 & 94.5 & 0.84 \\
\hline 9 & 39 & 13 & 82.7 & 1.76 & 26.7 & 22.7 & 60.1 & 29.2 & 4.10 & 96.0 & 99.0 & 0.97 \\
\hline 10 & 27 & 3 & 73.2 & 1.76 & 23.6 & 13.7 & 59.5 & 29.2 & 2.66 & 85.0 & 93.5 & 0.91 \\
\hline 11 & 32 & 3 & 80.6 & 1.69 & 28.2 & 22.4 & 58.2 & 27.6 & 3.64 & 92.5 & 103.0 & 0.90 \\
\hline 12 & 37 & 16 & 105 & 1.78 & 33.1 & 36.1 & 68.8 & 32.4 & 6.61 & 114.0 & 111.0 & 1.03 \\
\hline 13 & 44 & 13 & 82.1 & 1.81 & 25.1 & 20.9 & 61.2 & 29.1 & 3.28 & 91.5 & 102.0 & 0.90 \\
\hline 14 & 32 & 4 & 76.8 & 1.87 & 22.0 & 19.4 & 57.5 & 28.3 & 4.73 & 88.0 & 97.0 & 0.91 \\
\hline Mean & 35.6 & 10.4 & 88.6 & 1.79 & 27.7 & 26.0 & 62.7 & 30.7 & 4.00 & 96.3 & 103.6 & 0.93 \\
\hline SEM. & 1.57 & 2.15 & 3.75 & 0.01 & 1.23 & 3.09 & 1.40 & 0.77 & 0.55 & 3.52 & 2.44 & 0.02 \\
\hline \multicolumn{13}{|c|}{ NIGHT SHIFT $(n=11)$} \\
\hline 15 & 47 & 16 & 104.0 & 1.69 & 36.5 & 33.2 & 71.0 & 35.3 & 2.31 & 116.0 & 113.0 & 1.03 \\
\hline 16 & 26 & 3 & 83.1 & 1.77 & 26.5 & 18.9 & 64.2 & 31.2 & 3.05 & 91.0 & 98.0 & 0.93 \\
\hline 17 & 25 & 5 & 78.0 & 1.70 & 27.0 & 8.0 & 73.5 & 36.3 & 1.46 & 84.0 & 98.0 & 0.86 \\
\hline 18 & 28 & 4 & 97.9 & 1.67 & 35.1 & 10.5 & 49.8 & 24.0 & 2.26 & 112.0 & 112.0 & 1.00 \\
\hline 19 & 35 & 4 & 60.3 & 1.65 & 22.1 & 12.8 & 65.3 & 32.0 & 1.66 & 87.5 & 90.0 & 0.97 \\
\hline 20 & 25 & 5 & 82.2 & 1.87 & 23.5 & 19.9 & 63.3 & 30.4 & 2.86 & 84.0 & 96.5 & 0.87 \\
\hline 21 & 32 & 3 & 86.8 & 1.75 & 28.3 & 24.1 & 62.7 & 30.9 & 3.10 & 99.0 & 108.0 & 0.92 \\
\hline 22 & 24 & 2 & 82.0 & 1.74 & 27.1 & 20.7 & 66.1 & 31.7 & 1.69 & 91.5 & 102.0 & 0.90 \\
\hline 23 & 25 & 4 & 84.8 & 1.68 & 30.0 & 24.7 & 60.2 & 29.3 & 2.43 & 103.0 & 106.0 & 0.97 \\
\hline 24 & 38 & 16 & 72.4 & 1.62 & 27.6 & 18.2 & 54.3 & 25.0 & 2.19 & 93.0 & 98.0 & 0.95 \\
\hline 25 & 33 & 4 & 111.0 & 1.77 & 35.5 & 36.2 & 75.0 & 38.2 & 3.35 & 110.0 & 116.0 & 0.95 \\
\hline Mean & 30.7 & 6.0 & 85.7 & 1.7 & 29.0 & 20.7 & 64.1 & 31.3 & 2.40 & 97.4 & 103.4 & 0.94 \\
\hline SEM. & 2.17 & 1.51 & 4.31 & 0.02 & 1.45 & 2.63 & 2.29 & 1.30 & 0.19 & 3.44 & 2.47 & 0.02 \\
\hline \multicolumn{13}{|c|}{ TOTAL SAMPLE $(n=25)$} \\
\hline Mean & 33.5 & 8.4 & 87.3 & 1.76 & 28.3 & 23.7 & 63.3 & 31.0 & 3.3 & 96.8 & 103.5 & 0.93 \\
\hline SEM. & 1.36 & 1.42 & 2.78 & 0.01 & 0.93 & 2.11 & 1.26 & 0.70 & 0.35 & 2.44 & 1.71 & 0.01 \\
\hline
\end{tabular}

Abbreviations: *Years: service length (years) at the PMESP. BM: body mass; BMI: body mass index; AFM: absolute fat mass; FFM: fatfree mass: SMM: skeletal muscle mass; VAT: visceral adipose tissue; WC: waist circumference; HC: hip circumference; WHR: waist-hip ratio. Source authors (2021).

\section{Working length at PMESP}

The participants were also divided by the time they worked at the PMESP. Of the 25 participants, sixteen worked at 
the PMESP for 1 to 10 years, six worked for 11 to 19 years, and three for $>19$ years.

Clinical and laboratory data

Participants fasted for eight hours before blood samples were collected for determining plasma glucose, insulin, TG, HDL-cholesterol, CRP, and HbA1c concentrations. The estimated insulin resistance index (HOMA) was determined using the blood glucose and insulin levels (Matthews, et al., 1985). Resting blood pressure was measured with a Premium brand analog sphygmomanometer, following the procedures recommended by the 7th Brazilian Guideline of Arterial Hypertension (Malachias, et al., 2016). The Diagnosis and Analysis Center (CDA, São Paulo, SP, Brazil) conducted the laboratory measurements. Our group used the exact measurements in a previous study (Souza et al., 2021).

\section{Metabolic syndrome indicators}

Five criteria, based on Alberti et al., (2009) and the International Diabetes Federation (IDF), were used for diagnosing patients with MetS: 1) systolic blood pressure (SBP) >130 $\mathrm{mmHg}$ and diastolic blood pressure (DBP) >85 $\mathrm{mmHg}$; 2) male abdominal circumference $>90 \mathrm{~cm}$; 3) glycemia $>100 \mathrm{mg} / \mathrm{dL}$; 4) serum triacylglycerol TG concentration >150 mg/dL; and 5) plasma HDL-cholesterol levels $<40 \mathrm{mg} / \mathrm{dL}$ (Garbarino \& Magnavita, 2015). Patients with at least three of the five indicators were considered to have MetS. The same protocol was used in our previous study (Souza et al., 2021).

\section{Calculations performed using the results of the measurements mentioned above}

The number of steps each study participant took during the day or night shifts was evaluated according to service time, age, BMI and the clinical and laboratory measurements.

\section{Statistical analysis}

The data were analyzed using the PRISM software, version 9.0 (Graph Pad, San Diego USA). The level of significance adopted was 95\% ( $\mathrm{p}<0.05$ ). The Kolmogorov-Smirnov test was used for normal data distribution analysis. The Student's t-test (data with normal distribution) was used to compare two groups in the quantitative variables or the MannWhitney test (data without normality). One-way ANOVA with Tukey post-test was used to compare groups according to PMESP service time. For non-parametric data, the Kruskal-Wallis test was utilized. The Pearson's correlation test (data with normal distribution) or Spearman's test (data without normality) was used to check the relationship among measurements. The data are presented as percentages, and delta $(\Delta)$ values were calculated using the Excel program.

\section{Results}

The individual and average \pm SEM number of steps during the patrol shift, SBP and DBP (mmHg), fasting plasma levels of glucose (mg/dL), high glycated hemoglobin HbAlc (\%), TG (mg/dL), HDL (mg/dL), and CRP (mg/dL), and HOMA are presented in Table 2. The average number of steps for all volunteers $(n=25)$ was $5169 \pm 614$ during each $12 \mathrm{~h}$ shift. On average, the MPOs working the day shift took $4368 \pm 664$ steps, and those working the night shift took $6189 \pm 1069$ steps. While the MPOs patrolling at night performed $29.4 \%$ more steps than those of the day shift, this result failed to reach a level of statistical significance. 
Table 2. Average number of steps during work and plasma and clinical measurements in military police officers of the day $(n=14)$ and night $(n=11)$ shifts and total sample $(n=25)$. [São Paulo City, São Paulo State, Brazil,2018].

\begin{tabular}{|c|c|c|c|c|c|c|c|c|c|c|c|}
\hline \multicolumn{12}{|c|}{ DAY SHIFT $(n=14)$} \\
\hline & $\begin{array}{c}\text { STEPS } \\
\text { (number) }\end{array}$ & $\begin{array}{c}\text { SBP } \\
(\mathrm{mmHg})\end{array}$ & \multicolumn{2}{|r|}{$\begin{array}{c}\text { DBP } \\
(\mathrm{mmHg})\end{array}$} & $\begin{array}{l}\text { Glucose } \\
\text { (mg/dL) }\end{array}$ & $\begin{array}{c}\text { HbA1c } \\
\%\end{array}$ & $\begin{array}{c}\text { Insulin } \\
(\mu \mathrm{U} / \mathrm{mL})\end{array}$ & $\begin{array}{c}\text { HOMA } \\
\text { index }\end{array}$ & $\begin{array}{c}\text { TG } \\
(\mathrm{mg} / \mathrm{dL})\end{array}$ & $\begin{array}{c}\text { HDL } \\
(\mathrm{mg} / \mathrm{dL})\end{array}$ & $\begin{array}{c}\text { CRP } \\
(\mathrm{mg} / \mathrm{dL})\end{array}$ \\
\hline 1 & 4031 & 129 & & 77 & 86 & 5.71 & 11.0 & 2.33 & 468 & 41 & 0.07 \\
\hline 2 & 5251 & 140 & & 80 & 78 & 5.82 & 4.4 & 0.85 & 52 & 37 & 0.39 \\
\hline 3 & 4310 & 143 & & 83 & 99 & 6.01 & 27.1 & 6.62 & 229 & 34 & 0.27 \\
\hline 4 & 4220 & 138 & & 83 & 99 & 5.60 & 6.0 & 1.47 & 62 & 62 & 0.05 \\
\hline 5 & 3316 & 150 & & 80 & 95 & 5.22 & 15.0 & 3.52 & 149 & 31 & 0.08 \\
\hline 6 & 605 & 160 & & 90 & 103 & 5.70 & 21.5 & 5.46 & 188 & 49 & 0.30 \\
\hline 7 & 8225 & 128 & & 71 & 86 & 5.62 & 36.5 & 7.74 & 198 & 33 & 0.18 \\
\hline 8 & 10847 & 130 & & 70 & 96 & 5.31 & 32.7 & 7.74 & 138 & 44 & 0.01 \\
\hline 9 & 3466 & 134 & & 81 & 91 & 5.42 & 11.3 & 2.54 & 115 & 34 & 0.19 \\
\hline 10 & 2890 & 126 & & 72 & 84 & 5.58 & 35.4 & 7.33 & 127 & 46 & 0.09 \\
\hline 11 & 2731 & 128 & & 66 & 107 & 5.66 & 56.2 & 14.80 & 129 & 42 & 0.19 \\
\hline 12 & 3722 & 148 & & 82 & 105 & 5.70 & 58.1 & 15.10 & 184 & 47 & 0.31 \\
\hline 13 & 3275 & 112 & & 68 & 91 & 5.36 & 8.0 & 1.80 & 69 & 47 & 0.18 \\
\hline 14 & 4257 & 121 & & 82 & 100 & 5.67 & 12.5 & 3.08 & 48 & 59 & 0.16 \\
\hline Mean & 4367.6 & 134.8 & & 77.5 & 94.3 & 5.60 & 24.0 & 5.7 & 154.0 & 43.3 & 0.2 \\
\hline SEM. & 664.41 & 3.38 & & 1.87 & 2.30 & 0.06 & 4.74 & 1.22 & 28.58 & 2.50 & 0.03 \\
\hline \multicolumn{12}{|c|}{ NIGHT SHIFT (n=11) } \\
\hline 15 & 7075 & 140 & 80 & 87 & 6.09 & 51 & 1.09 & 179 & 25 & & 0.46 \\
\hline 16 & 5335 & 140 & 70 & 91 & 5.37 & 3.7 & 0.83 & 78 & 42 & & 0.01 \\
\hline 17 & 12811 & 140 & 80 & 93 & 5.66 & 2.5 & 0.57 & 36 & 82 & & 0.1 \\
\hline 18 & 1883 & 120 & 90 & 101 & 6.12 & 17 & 4.24 & 94 & 46 & & 0.36 \\
\hline 19 & 4534 & 126 & 80 & 83 & 5.39 & 5.7 & 1.17 & 73 & 53 & & 0.2 \\
\hline 20 & 3172 & 120 & 70 & 86 & 5.53 & 7.6 & 1.61 & 145 & 34 & & 0.01 \\
\hline 21 & 2888 & 133 & 80 & 101 & 5.81 & 9.3 & 2.32 & 96 & 49 & & 0.06 \\
\hline 22 & 9594 & 110 & 73 & 97 & 5.53 & 35.5 & 8.49 & 355 & 31 & & 0.27 \\
\hline 23 & 5793 & 110 & 60 & 83 & 5.75 & 10.1 & 2.07 & 76 & 44 & & 0.41 \\
\hline 24 & 4043 & 100 & 60 & 86 & 5.18 & 7.6 & 1.61 & 95 & 41 & & 0.29 \\
\hline 25 & 10947 & 110 & 70 & 87 & 6.21 & 92 & 19.7 & 353 & 38 & & 0.27 \\
\hline Mean & 6188.6 & 122.6 & 73.9 & 90.5 & 5.7 & 22.0 & 4.0 & 143.6 & 44.1 & & 0.22 \\
\hline SEM & 1068.7 & 4.29 & 2.76 & 2.0 & 0.1 & 8.3 & 1.7 & 33.3 & 4.5 & & 0.04 \\
\hline \multicolumn{12}{|c|}{ TOTAL SAMPLE $(n=25)$} \\
\hline $\begin{array}{l}\text { Mean } \\
\text { SEM } \\
\end{array}$ & $\begin{array}{c}5169 \\
614 \\
\end{array}$ & $\begin{array}{c}129.4 \\
2.89 \\
\end{array}$ & $\begin{array}{l}75.9 \\
1.61 \\
\end{array}$ & $\begin{array}{l}92.6 \\
1.58 \\
\end{array}$ & $\begin{array}{l}5.64 \\
0.05 \\
\end{array}$ & $\begin{array}{l}23.1 \\
4.43 \\
\end{array}$ & $\begin{array}{l}4.96 \\
1.01 \\
\end{array}$ & $\begin{array}{c}149.4 \\
21.3 \\
\end{array}$ & $\begin{array}{l}43.6 \\
2.37 \\
\end{array}$ & & $\begin{array}{l}0.19 \\
0.02 \\
\end{array}$ \\
\hline
\end{tabular}

Abbreviations: STEPS: Number of steps during work; SBP: systolic blood pressure. DBP: diastolic blood pressure; Hb A1c = high glycated hemoglobin A1c; HOMA (homeostatic model assessment) - insulin resistance indicator; TG = triacylglycerol; HDL = high-density lipoprotein; CRP: C-reactive protein. Source authors (2021).

For all MPOs, the SBP and DBP were $129.4 \pm 2.89$ and $75.9 \pm 1.61 \mathrm{mmHg}$, respectively. When considered separately, the day shift group presented average SBP and DBP of $134.8 \pm 3.38$ and $77.5 \pm 1.87 \mathrm{mmHg}$, and the night shift group had values 
of $122.6 \pm 4.29$ and $73.9 \pm 2.76 \mathrm{mmHg}$. Moreover, the SBP of the day shift MPOs ranged from 112 to $160 \mathrm{mmHg}$ and 100 to 140 $\mathrm{mmHg}$ for the night shift. The DBP ranged from 66 to $90 \mathrm{mmHg}$ and 60 to $90 \mathrm{mmHg}$ for the MPOs working the day and night shift, respectively. Considering individual values, we found that seven day shift MPOs presented an SBP above $130 \mathrm{mmHg}$, and one had a DBP above $85 \mathrm{mmHg}$. In the night shift group, four MPOs had an SBP above $130 \mathrm{mmHg}$, and one had a DBP above $85 \mathrm{mmHg}$. Overall, 13 of the 25 MPOs were hypertensive (52\%), with two only having elevated DBP, ten only having elevated SBP and one having both SBP and DBP elevated.

The fasting glycemia of all volunteers was $92.6 \pm 1.58 \mathrm{mg} / \mathrm{dL}$, a value within the normal levels ( $\leq 99 \mathrm{mg} / \mathrm{dL}$ ) (Xavier, et al., 2013). Four day and two night shift MPOs exhibited fasting hyperglycemia ( $\geq 100 \mathrm{mg} / \mathrm{dL})$. Concerning HbA1c, $56 \%$ of the participants ( $\mathrm{n}=8$ from the day shift and $\mathrm{n}=6$ from the night shift) had values above normal (i.e., $\leq 5.6 \%$ ) (American Diabetes Association, 2018). The insulinemia of all participants was $23.1 \pm 4.43 \mu \mathrm{U} / \mathrm{mL}$, with values ranging from 4.4 to $58.1 \mu \mathrm{U} / \mathrm{mL}$ ( $\Delta=53.7$ ) for the day shift group and 2.5 to $92 \mu \mathrm{U} / \mathrm{mL}(\Delta=89.5)$ in the night shift group. The HOMA-IR of all participants was $4.96 \pm 1.01$. Notably, the mean HOMA-IR values of the day shift group were significantly greater than the night shift group $[5.74 \pm 1.22$ vs. $3.68 \pm 1.60$, respectively $(\mathrm{p}<0.04)]$. Additionally, 11 of the day shift and four of the night shift MPOs were insulin resistant, representing $60 \%$ of the total sample.

Plasma TG levels of all participants were $149 \pm 21.3 \mathrm{mg} / \mathrm{dL}$, slightly below the normal value of $<150 \mathrm{mg} / \mathrm{dL}$ (SPOSITO, et al., 2007). A total of eight MPOs (32\% of the total sample), five from the day and three from the night shift, presented elevated values. The average plasma HDL value of all participants was $43.6 \pm 2.37 \mathrm{mg} / \mathrm{dL}$. While the average plasma HDL value was $>40 \mathrm{mg} / \mathrm{dL}$, which is considered normal for adults (Xavier, et al., 2013), five of the day and four of the night shift MPOs had low values (i.e., $36 \%$ of the total). Finally, the plasma CRP levels of all participants ranged from 0.07 to 0.46 , values within the normal range $(<0.60 \mathrm{mg} / \mathrm{dL})$ (Roberts et al., 2001).

Correlations of the number of steps during the work, service time (years) at the PMESP, age and BMI with BM, AFM, FFM, SMM, VAT, WC, HC, WHR, SBP, DBP, glucose, HbA1c, insulin, HOMA-IR, TG, HDL and CRP of all volunteers are presented in Figure 1.

The number of steps was positively correlated with FFM $(r=0.40 ; p<0.05)$ and SMM $(r=0.44 ; p<0.05)$. The number of years of work at the PMESP correlated positively with WC ( $\mathrm{r}=0.52$; $\mathrm{p}<0.01)$, WHR $(\mathrm{r}=0.57 ; \mathrm{p}<0.01)$, and AFM $(\mathrm{r}=0.46$; $\mathrm{p}<0.05)$. There was a positive trend with BM $(r=0.35 ; \mathrm{p}=0.08)$ and SBP $(\mathrm{r}=0.35 ; \mathrm{p}=0.08)$. The age of the volunteers was positively correlated with WC $(r=0.57 ; \mathrm{p}<0.01)$, WHR $(r=0.55 ; \mathrm{p}<0.01)$, AFM $(r=0.57 ; \mathrm{p}<0.01)$ and VAT $(r=0.45 ; \mathrm{p}<0.05)$. There was a positive trend of age with BM $(r=0.36 ; p=0.08)$ and SBP $(r=0.34 ; p=0.09)$. BMI was associated with a trend towards years of work at the PMESP $(r=0.36 ; \mathrm{p}=0.08)$ and age $(\mathrm{r}=0.34 ; \mathrm{p}=0.08)$, and a significant correlation with CRP $(\mathrm{r}=0.65 ; \mathrm{p}<0.001)$, TG $(\mathrm{r}=0.44 ; \mathrm{p}<0.05)$, insulin $(\mathrm{r}=0.48 ; \mathrm{p}<0.05)$, HbA1c $(\mathrm{r}=0.59 ; \mathrm{p}<0.05)$ and as expected, with body composition: AFM ( $r=0.65 ; \mathrm{p}<0.001)$, WC $(r=0.88 ; \mathrm{p}<0.001)$, and WHR $(r=0.65 ; \mathrm{p}<0.001)$.

Based on the collected data and analyses, it was determined that nine day $(64.2 \%)$ and seven night $(63.6 \%)$ shift MPOs exhibited MetS, which corresponds to $64 \%$ of the total sample. 
Figure 1. Correlation matrix heat map. Body composition, plasma and work variables of 25 military police officers in the radio patrol. Data analyzed by Spearman correlation. Significance level *p<0.05. \&Trend significance.

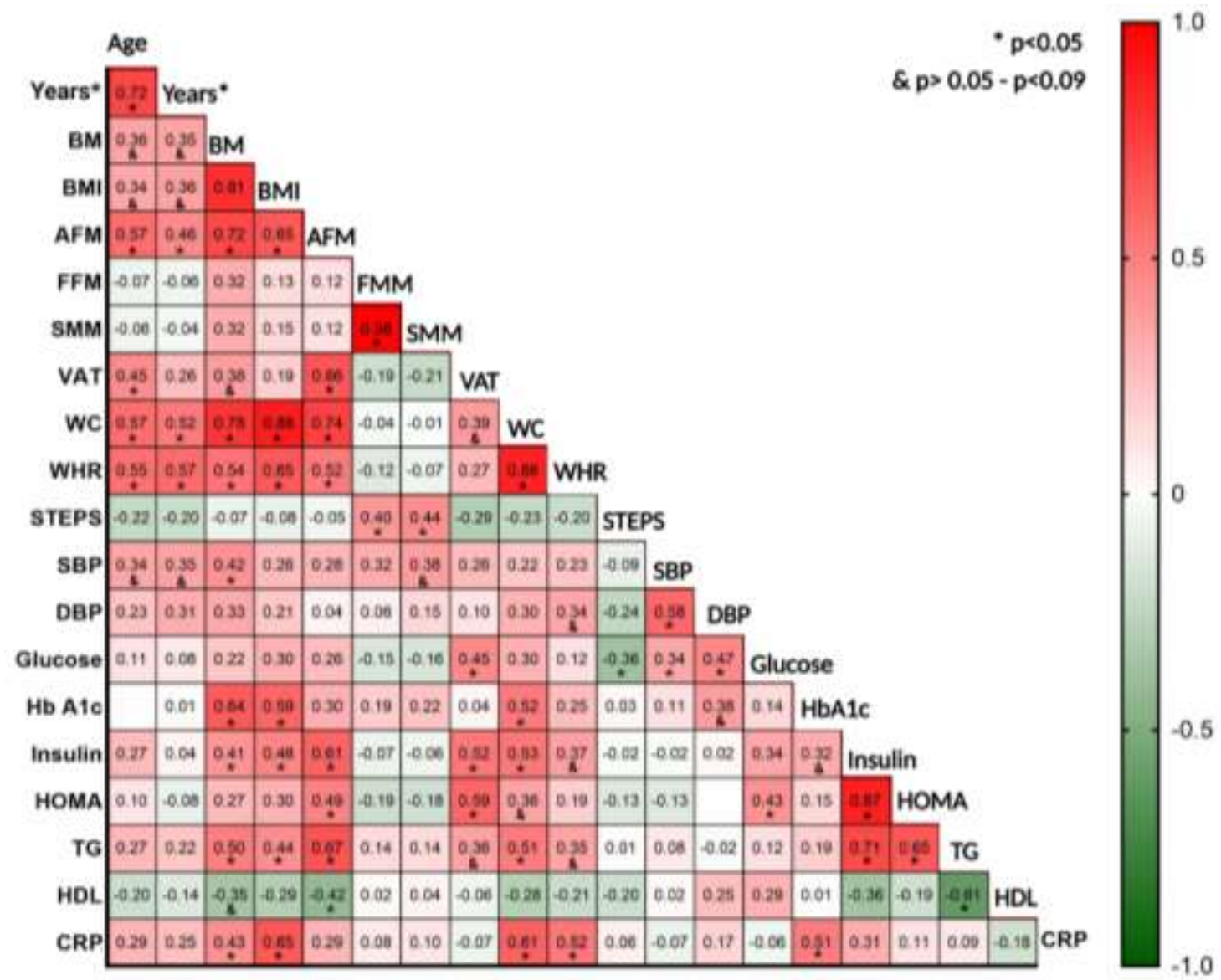

Abbreviations: *Years: working length (years) in the Corporation.; BM: body mass; BMI: body mass index; AFM: absolute fat mass; FFM: fat-free mass: SMM: skeletal muscle mass; VAT: visceral adipose tissue; WC: waist circumference; HC: hip circumference; WHR: waist-hip ratio; STEPS: Number of steps during work shift; SBP: systolic blood pressure. DBP: diastolic blood pressure; Hb A1c = high glycated hemoglobin A1c; HOMA (homeostatic model assessment) - insulin resistance indicator; $\mathrm{TG}=$ triacylglycerol; HDL $=$ high-density lipoprotein; CRP: C-reactive protein. Source authors (2021).

\section{Discussion}

In the present study, we evaluated the number of steps taken by MPOs during their $12 \mathrm{~h}$ patrols. Twelve hours comprise most of the day, considering the hours of sleep and the commute to work. The study of Tudor-Locke (2011) was used to interpret the results.

The average number of steps performed by the 25 MPOs over $12 \mathrm{~h}$ was 5169 . The MPOs working the day shift took 4368 steps, and those working the night shift took 6189. The number of steps during the MPOs patrol, regardless of the shift, was less than 7000 steps, which is relatively low and corresponds to little daily activity. Even though it is only during the working period, this data represents about $75 \%$ of daytime MPOs' daily activity and $92 \%$ of those patrolling at night (data not shown). Although not significant, the MPOs working the night shift walked $29.4 \%$ more (1820 steps). This result is likely because there are fewer police reports at night.

There was no statistical difference in BMI between group 1 (600-2,000 steps) and group 2 (2,001-8,000 steps). We also did not detect significant differences in FFM and SMM between these two groups. Krumm et al., (2006) examined the relationship between daily steps measured using a pedometer and body composition parameters in 93 menopausal women and reported a linear relationship between steps performed and BMI. Moreover, women who took 5,000 to 7,500 steps per day had 
lower BMI values than those who took less than 5,000 steps per day. Interestingly, there was no significant difference in BMI between women who took 7,500-9,999 steps per day and those who performed more than 10,000. Our data indicate that other factors, probably specific to radio patrol policing rather than physical activity, are involved in our findings.

We found higher BMI values in the group with >19 years of service than those with 1-10 years; however, the values were not significant $(\mathrm{p}<0.08)$. Additionally, BM (tendency, $\mathrm{p}<0.07)$ and AFM $(\mathrm{p}<0.01)$ were increased in the $>19$ years of service compared to the group with 1-10 years. These findings suggest that the MPOs who worked at the PMESP for a longer period display abnormal body composition, possibly contributing to the onset and progression of MetS.

Although we did not detect a statistical difference in the VAT, MPOs who performed a greater working number of steps (WNS) exhibited improved health parameters. On the other hand, the VAT increases with age and service length at the PMESP. The metabolic benefits that physical activity promotes are well known, and the consequences of low physical activity are associated with high VAT. Thus, the reduced number of steps taken by all MPOs probably contributed to the elevated VAT values. Notably, this condition is associated with peripheral insulin resistance and MetS prevalence (Lee \& Kim, 2013), and frequent and intense physical activity significantly reduces VAT (Ismail, et al., 2012; Vissers, et al., 2013).

Additionally, WHR is one of the predictive risk markers for MetS development (Bener, et al., 2013), and the MPOs who performed the fewest WNS had the highest WHR values. It should be pointed out that $31 \%$ of the volunteers were classified as at very high risk, $42 \%$ at high risk, and $27 \%$ at moderate risk of developing cardiometabolic diseases.

The American Diabetes Association (2020) established desirable values for fasting glycemia, between 70 and 99 $\mathrm{mg} / \mathrm{dL}$. Herein, 16 of the 25 volunteers had abnormally high blood fasting glucose levels. Moreover, according to the American Diabetes Association (2020) reference values, 14 of the 25 participants (56\%) presented elevated HbA1c values above the recommended value of 5.6\%, indicative of chronic hyperglycemia. Of the 14 participants with elevated $\mathrm{HbA} 1 \mathrm{c}$ levels, one-third walked more than 5,000 steps during their patrol shift. Interestingly, the MPOs with the highest plasma insulin levels also had the highest HbA1c values. These results indicate a simultaneous occurrence of low physical activity levels and chronic hyperglycemia. Indeed, it is well established that insufficient physical activity contributes to hyperglycemia and type-2 diabetes development (Gill \& Cooper, 2008).

It is known that hypertriglyceridemia is a risk factor for acute myocardial infarction and stroke (Bays et al., 2013) and that there is a close association between hypertriglyceridemia and a sedentary lifestyle (Edwardson, et al., 2012). In the present study, eight (36\%) of the 25 volunteers presented hypertriglyceridemia; however, we could not detect a relationship between the number of steps and high plasma TG levels. Thus, it is plausible that other factors, such as age, family history, gender, smoking, drinking, arterial hypertension, abdominal overweight, obesity, a diet rich in animal fats, and stress, contribute to this observation (Faludi, et al., 2017). The group with the longest service time in the PMESP had TG values above normal, suggesting that this factor contributed to the observed hypertriglyceridemia.

It has been reported that plasma HDL-cholesterol levels below $40 \mathrm{mg} / \mathrm{dL}$ are associated with physical inactivity and MetS risk (Celis-Morales et al., 2012). Herein, 38\% of the MPOs had low HDL levels. Moreover, MPOs with $\geq 19$ years of service at the PMESP presented HDL levels below $40 \mathrm{mg} / \mathrm{dL}$. The participants with more years of service walked less during their patrol shift $(2743.17 \pm 1107.16$ steps/day) and presented low HDL values.

Our analysis of SBP and DBP indicates that $52 \%$ of the policemen had hypertension. The group that performed up to 2,000 steps daily presented significantly increased DBP. Moreover, the MPOs with the longer service time in the PMESP presented considerably elevated SBP. Finally, low WNS and more years at the PMESP were associated with aggravated hypertension.

Madjd et al., (2019) studied 65 sedentary, overweight or obese women who underwent two types of physical activity programs with a controlled diet to generate a daily caloric deficit of 500-600 calories for 24 weeks. One group had a long and 
continuous walking protocol, with at least 100 steps per min for $50 \mathrm{~min}$, six times a week and the other group walked twice a day for $25 \mathrm{~min}$, six times a week. Under these conditions, the physical activity volumes were equalized. Before starting the

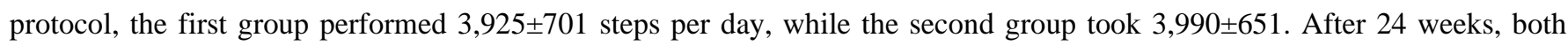
groups significantly increased the number of steps, with the first group exhibiting an increase of $+2196 \pm 789$ steps per day and the second group increased the number of daily steps by $+2965 \pm 795$. While both groups presented increased plasma HDL levels and reduced BM, BMI, WC, and total cholesterol, HbAlc, glucose, and insulin blood levels, the second group displayed more expressive results that could contribute to cardiometabolic disease prevention.

Vancini et al., (2018) described the relationship between symptoms of anxiety and depression and the level of habitual physical activity in male MPOs from the State of Espirito Santo, Brazil (who routinely deal with extraordinarily complex and hostile situations), according to the BMI. They observed that the overweight group had increased anxiety and depression associated with low physical activity levels. Additionally, the MPOs with the highest BMI had the most marked symptoms. These changes may be related to the number of military service years.

There are some limitations to take into consideration in analyzing our results. For example, we only studied male MPOs. A paired control group would be desirable, but it is difficult to define appropriate professional work for comparison. Moreover, we did not record the physical activity for $24 \mathrm{~h}$. Lastly, despite providing proper teaching and support for the participants' to use and handle the pedometers and recording the number of steps during their patrol shift, the number of participants excluded from the study due to improper pedometer use was high.

\section{Final Considerations}

In conclusion, the occurrence of MetS increases in MPOs with more years of service at the PMESP. The number of daily steps taken by MPOs during their patrol indicates that the majority are not physically active. Additionally, these individuals presented unhealthy body compositions and plasma measurements associated with a high MetS prevalence (64\%). Notably, all MPOs working at the PMESP for more than 19 years performed the fewest number of steps during work (up to 2,000 steps) and presented MetS. Intervention strategies are needed to increase physical activity practice during work and to prevent and treat the occurrence of metabolic changes in MPOs.

\section{Acknowledgments}

FAPESP, CNPq, CAPES, the Guggenheim Foundation, Cruzeiro do Sul University, and Maringa State University financially supported this study. The authors are grateful to the constant support of Professors Luiz Henrique do Amaral (Academic Director) and Renato Padovese (President) of the Grupo Cruzeiro do Sul Educacional, and Coronel PM Fernando Alencar Medeiros, the PMESP Chief Commander.

\section{References}

Alberti, K. G., Eckel, R. H., Grundy, S. M., Zimmet, P. Z., Cleeman, J. I., \& Donato, K. A. (2009). Harmonizing the metabolic syndrome: a joint interim statement of the International Diabetes Federation Task Force on Epidemiology and Prevention; National Heart, Lung, and Blood Institute; American Heart Association; World Heart Federation; International Atherosclerosis Society; and International Association for the Study of Obesity. Circulation, 120(16), 1640-1645. https://doi.org/10.1161/CIRCULATIONAHA.109.192644.

Association, A. D. (2018). 2. Classification and diagnosis of diabetes: standards of medical care in diabetes-2018. Diabetes care, 41(Supplement 1), S13S27.

Association, A. D. (2020). 2. Classification and Diagnosis of Diabetes: Standards of Medical Care in Diabetes-2020. Diabetes Care, $43($ Suppl 1), S14.

Baughman, P., Andrew, M. E., Burchfiel, C. M., Fekedulegn, D., Hartley, T. A., Violanti, J. M., \& Miller, D. B. (2016). High-protein meal challenge reveals the association between the salivary cortisol response and metabolic syndrome in police officers. American Journal of Human Biology, 28(1), $138-144$. 
Bays, H. E., Toth, P. P., Kris-Etherton, P. M., Abate, N., Aronne, L. J., Brown, W. V., \& La Forge, R. (2013). Obesity, adiposity, and dyslipidemia: a consensus statement from the National Lipid Association. Journal of clinical lipidology, 7(4), 304-383.

Bazotte, R. B., Silva, L. G., \& Schiavon, F. P. (2014). Insulin resistance in the liver: deficiency or excess of insulin? Cell Cycle, 13(16), 2494-2500.

Bener, A., Yousafzai, M. T., Darwish, S., Al-Hamaq, A. O., Nasralla, E. A., \& Abdul-Ghani, M. (2013). Obesity index that better predict metabolic syndrome: body mass index, waist circumference, waist hip ratio, or waist height ratio. Journal of obesity, 2013.

Bosy-Westphal, A., Schautz, B., Later, W., Kehayias, J., Gallagher, D., \& Müller, M. (2013). What makes a BIA equation unique? Validity of eight-electrode multifrequency BIA to estimate body composition in a healthy adult population. European journal of clinical nutrition, 67(1), S14-S21.

Bull, F. C., Al-Ansari, S. S., Biddle, S., Borodulin, K., Buman, M. P., Cardon, G., \& Chou, R. (2020). World Health Organization 2020 guidelines on physical activity and sedentary behaviour. British journal of sports medicine, 54(24), 1451-1462.

Celis-Morales, C. A., Perez-Bravo, F., Ibañez, L., Salas, C., Bailey, M. E., \& Gill, J. M. (2012). Objective vs. self-reported physical activity and sedentary time: effects of measurement method on relationships with risk biomarkers. PloS one, 7(5), e36345.

Chang, J.-H., Huang, P.-T., Lin, Y.-K., Lin, C.-E., Lin, C.-M., Shieh, Y.-H., \& Lin, Y.-C. (2015). Association between sleep duration and sleep quality, and metabolic syndrome in Taiwanese police officers. International journal of occupational medicine and environmental health, $28(6), 1011$.

Clinical Guidelines on the Identification, Evaluation, and Treatment of Overweight and Obesity in Adults--The Evidence Report. National Institutes of Health. (1998). Obesity research, 6 Suppl 2, 51S-209S."

De Onis, M., \& Habicht, J.-P. (1996). Anthropometric reference data for international use: recommendations from a World Health Organization Expert Committee. The American journal of clinical nutrition, 64(4), 650-658.

de Souza, D. R., da Silva Junior, E. P., de Moura, J. R., Junior, J. R. L., Pires, A. C. L., Curi, R., \& Pithon-Curi, T. C. (2018). Efficacy of a Health Promotion Guidance Program Applied to the Police of São Paulo City. Journal of Archives in Military Medicine, 6(4).

Ekblom-Bak, E., Halldin, M., Vikström, M., Stenling, A., Gigante, B., de Faire, U., \& Hellénius, M.-L. (2021). Physical activity attenuates cardiovascular risk and mortality in men and women with and without the metabolic syndrome-a 20-year follow-up of a population-based cohort of 60-year-olds. European journal of preventive cardiology, 28(12), 1376-1385

Esposito, K., Chiodini, P., Colao, A., Lenzi, A., \& Giugliano, D. (2012). Metabolic syndrome and risk of cancer: a systematic review and meta-analysis. Diabetes care, 35(11), 2402-2411.

Faludi, A. A., Izar, M. C. O., Saraiva, J. F. K., Chacra, A. P. M., Bianco, H. T., Afiune, A. N., \& Salgado, W. F. (2017). [Not Available]. Arq Bras Cardiol, 109(2 Supl 1), 1-76. https://doi.org/10.5935/abc.20170121 (Atualização da Diretriz Brasileira de Dislipidemias e Prevenção da Aterosclerose - 2017.)

Filho, R. T. B., \& D'Oliveira Jr, A. (2014). The prevalence of metabolic syndrome among soldiers of the military police of Bahia state, Brazil. American Journal of Men's Health, 8(4), 310-315.

Friedenreich, C. M., Neilson, H. K., O’Reilly, R., Duha, A., Yasui, Y., Morielli, A. R., \& Courneya, K. S. (2015). Effects of a high vs moderate volume of aerobic exercise on adiposity outcomes in postmenopausal women: a randomized clinical trial. JAMA oncology, 1(6), 766-776.

Garbarino, S., \& Magnavita, N. (2015). Work Stress and Metabolic Syndrome in Police Officers. A Prospective Study. PLoS One, 10(12), e0144318. https://doi.org/10.1371/journal.pone.0144318

Gill, J. M., \& Cooper, A. R. (2008). Physical activity and prevention of type 2 diabetes mellitus. Sports Medicine, 38(10), 807-824.

Green, A. N., McGrath, R., Martinez, V., Taylor, K., Paul, D. R., \& Vella, C. A. (2014). Associations of objectively measured sedentary behavior, light activity, and markers of cardiometabolic health in young women. European journal of applied physiology, 114(5), 907-919.

Grundy, S. M., Brewer Jr, H. B., Cleeman, J. I., Smith Jr, S. C., \& Lenfant, C. (2004). Definition of metabolic syndrome: report of the National Heart, Lung, and Blood Institute/American Heart Association conference on scientific issues related to definition. Circulation, 109(3), 433-438.

Hoffmann, T. C., Maher, C. G., Briffa, T., Sherrington, C., Bennell, K., Alison, J., \& Glasziou, P. P. (2016). Prescribing exercise interventions for patients with chronic conditions. Can Med Assoc Jounal, 188(7), 510-518.

Ismail, I., Keating, S., Baker, M., \& Johnson, N. (2012). A systematic review and meta-analysis of the effect of aerobic vs. resistance exercise training on visceral fat. Obesity reviews, 13(1), 68-91.

JI, A. R. (2019). Sedentary lifestyle a disease from xxi century. Clinica e investigacion en arteriosclerosis: publicacion oficial de la Sociedad Espanola de Arteriosclerosis, 31(5), 233-240.

Kraus, W. E., Janz, K. F., Powell, K. E., Campbell, W. W., Jakicic, J. M., Troiano, R. P., \& Committee, P. A. G. A. (2019). Daily step counts for measuring physical activity exposure and its relation to health. Medicine and science in sports and exercise, 51(6), 1206.

Krumm, E. M., Dessieux, O. L., Andrews, P., \& Thompson, D. L. (2006). The relationship between daily steps and body composition in postmenopausal women. Journal of women's health, 15(2), 202-210.

Lavie, C. J., Ozemek, C., Carbone, S., Katzmarzyk, P. T., \& Blair, S. N. (2019). Sedentary Behavior, Exercise, and Cardiovascular Health. Circ Res, 124(5), 799-815. https://doi.org/10.1161/CIRCRESAHA.118.312669

Lee, S., \& Kim, Y. (2013). Effects of exercise alone on insulin sensitivity and glucose tolerance in obese youth. Diabetes \& metabolism journal, 37(4), 225232. 
Leiva, A. M., Martínez, M. A., Cristi-Montero, C., Salas, C., Ramírez-Campillo, R., Aguilar-Farías, N., \& Celis-Morales, C. (2017). Sedentary lifestyle is associated with metabolic and cardiovascular risk factors independent of physical activity. Revista médica de Chile, 145(4), 458-467.

Madjd, A., Taylor, M. A., Delavari, A., Malekzadeh, R., Macdonald, I. A., \& Farshchi, H. R. (2019). Effect of a Long Bout Versus Short Bouts of Walking on Weight Loss During a Weight-Loss Diet: A Randomized Trial. Obesity, 27(4), 551-558.

Malachias, M. V. B., Bortolotto, L. A., Drager, L. F., Borelli, F. A. O., Lotaif, L. A. D., \& Martins, L. C. (2016). 7th Brazilian Guideline of Arterial Hypertension: Chapter 12 - Secondary Arterial Hypertension. Arq Bras Cardiol, 107(3 Suppl 3), 67-74. https://doi.org/10.5935/abc.20160162 (7ª Diretriz Brasileira de Hipertensão Arterial: Capítulo 12 - Hipertensão Arterial Secundária.)

Matthews, D. R., Hosker, J. P., Rudenski, A. S., Naylor, B. A., Treacher, D. F., \& Turner, R. C. (1985). Homeostasis model assessment: insulin resistance and beta-cell function from fasting plasma glucose and insulin concentrations in man. Diabetologia, 28(7), 412-419. https://doi.org/10.1007/BF00280883

McPhee, J. S., French, D. P., Jackson, D., Nazroo, J., Pendleton, N., \& Degens, H. (2016). Physical activity in older age: perspectives for healthy ageing and frailty. Biogerontology, 17(3), 567-580.

Merino, P. S. (2010). Mortalidade em efetivos da polícia militar do Estado de São Paulo. Universidade Federal de São Paulo.

Murtagh, E. M., Murphy, M. H., \& Boone-Heinonen, J. (2010). Walking-the first steps in cardiovascular disease prevention. Current opinion in cardiology, $25(5), 490$.

Myers, J., Kokkinos, P., \& Nyelin, E. (2019). Physical Activity, Cardiorespiratory Fitness, and the Metabolic Syndrome. Nutrients, 11(7). https://doi.org/10.3390/nu11071652

Neeland, I., Ross, R., Després, J., Matsuzawa, Y., Yamashita, S., Shai, I., . . Arsenault, B. (2019). International Atherosclerosis Society; International Chair on Cardiometabolic Risk Working Group on Visceral Obesity. Visceral and ectopic fat, atherosclerosis, and cardiometabolic disease: a position statement. Lancet Diabetes Endocrinol, 7(9), 715-725.

Neeland, I. J., Singh, S., McGuire, D. K., Vega, G. L., Roddy, T., Reilly, D. F., \& Scherer, P. E. (2018). Relation of plasma ceramides to visceral adiposity, insulin resistance and the development of type 2 diabetes mellitus: the Dallas Heart Study. Diabetologia, 61(12), 2570-2579.

Paterson, D. H., \& Warburton, D. E. (2010). Physical activity and functional limitations in older adults: a systematic review related to Canada's Physical Activity Guidelines. International Journal of Behavioral Nutrition and Physical Activity, 7(1), 1-22.

Payab, M., Hasani-Ranjbar, S., Merati, Y., Esteghamati, A., Qorbani, M., Hematabadi, M., \& Shirzad, N. (2017). The prevalence of metabolic syndrome and different obesity phenotype in Iranian male military personnel. American journal of men's health, 11(2), 404-413.

Penedo, F. J., \& Dahn, J. R. (2005). Exercise and well-being: a review of mental and physical health benefits associated with physical activity. Current opinion in psychiatry, 18(2), 189-193.

Roberts, W. L., Moulton, L., Law, T. C., Farrow, G., Cooper-Anderson, M., Savory, J., \& Rifai, N. (2001). Evaluation of nine automated high-sensitivity Creactive protein methods: implications for clinical and epidemiological applications. Part 2. Clinical chemistry, 47(3), 418-425.

Schneider, P. L., Crouter, S. E., Lukajic, O., \& Bassett Jr, D. R. (2003). Accuracy and reliability of 10 pedometers for measuring steps over a 400-m walk. Medicine and science in sports and exercise, 35(10), 1779-1784.

Souza, D. R. d., Silva, E. N. d., Santos, L. P. d., Oliveira, L. C. d. S. d., Augusto, D. T., Silva, E. B. d., \& Pithon-Curi, T. C. (2021). Prevalence of Metabolic Syndrome in Military Police Officers of São Paulo City: The Health Promotion in Military Police (HPMP) Study. Research, Society and Development, 10(14), e61101421142. https://doi.org/10.33448/rsd-v10i14.21142

Sposito, A. C., Caramelli, B., Fonseca, F. A., Bertolami, M. C., Afiune Neto, A., Souza, A. D., \& Loures-Vale, A. A. (2007). IV Diretriz brasileira sobre dislipidemias e prevenção da aterosclerose: Departamento de Aterosclerose da Sociedade Brasileira de Cardiologia. Arquivos brasileiros de cardiologia, 88, 2 19.

Tharkar, S., Kumpatla, S., Muthukumaran, P., \& Viswanathan, V. (2008). High prevalence of metabolic syndrome and cardiovascular risk among police personnel compared to general population in India. J Assoc Physicians India, 56, 845-849.

Thornton, J. S., Frémont, P., Khan, K., Poirier, P., Fowles, J., Wells, G. D., \& Frankovich, R. J. (2016). Physical activity prescription: a critical opportunity to address a modifiable risk factor for the prevention and management of chronic disease: a position statement by the Canadian Academy of Sport and Exercise Medicine. British journal of sports medicine, 50(18), 1109-1114.

Tudor-Locke, C., Craig, C. L., Brown, W. J., Clemes, S. A., De Cocker, K., Giles-Corti, B., \& Mutrie, N. (2011). How many steps/day are enough? For adults. International Journal of Behavioral Nutrition and Physical Activity, 8(1), 1-17.

Tudor-Locke, C., Johnson, W. D., \& Katzmarzyk, P. T. (2009). Accelerometer-determined steps per day in US adults. Medicine and science in sports and exercise, 41(7), 1384-1391.

Vancini, R. L., de Lira, C. A., Anceschi, S. A., Rosa, A. V., Lima-Leopoldo, A. P., Leopoldo, A. S., \& Rosemann, T. (2018). Anxiety, depression symptoms, and physical activity levels of eutrophic and excess-weight Brazilian elite police officers: a preliminary study. Psychology research and behavior management, 11, 589 .

Violanti, J. M., Burchfiel, C. M., Hartley, T. A., Mnatsakanova, A., Fekedulegn, D., Andrew, M. E., \& Vila, B. J. (2009). Atypical work hours and metabolic syndrome among police officers. Archives of environmental \& occupational health, 64(3), 194-201. 
Research, Society and Development, v. 11, n. 2, e13511225376, 2022

(CC BY 4.0) | ISSN 2525-3409 | DOI: http://dx.doi.org/10.33448/rsd-v11i2.25376

Vissers, D., Hens, W., Taeymans, J., Baeyens, J.-P., Poortmans, J., \& Van Gaal, L. (2013). The effect of exercise on visceral adipose tissue in overweight adults: a systematic review and meta-analysis. PloS one, 8(2), e56415.

Warburton, D. E., \& Bredin, S. S. (2016). Reflections on physical activity and health: what should we recommend? Canadian Journal of Cardiology, 32(4), 495-504.

Warburton, D. E., Nicol, C. W., \& Bredin, S. S. (2006). Health benefits of physical activity: the evidence. Can Med Assoc Jounal, 174(6), 801-809.

Xavier, H., Izar, M., Neto, J. F., Assad, M., Rocha, V., Sposito, A., \& Bertolami, M. (2013). V Brazilian guidelines on dyslipidemias and prevention of atherosclerosis. Arquivos brasileiros de cardiologia, 101(4 Suppl 1), 1-20. 